\title{
Numerical Analysis of Total Fatty Acid Profiles in the Identification of Coryneform, Nocardioform and Some Other Bacteria
}

\author{
By I. J. BOUSFIELD, ${ }^{*}$ G. L. SMITH, ${ }^{2}$ T. R. DANDO ${ }^{1}$ AND G. HOBBS ${ }^{1}$ \\ National Collections of Industrial and Marine Bacteria ${ }^{1}$ and Computing and Statistics Section ${ }^{2}$, \\ Ministry of Agriculture, Fisheries and Food, Torry Research Station, P.O. Box 31, \\ 135 Abbey Road, Aberdeen AB9 8DG, U.K.
}

(Received 5 April 1982; revised 2 July 1982)

\begin{abstract}
Fatty acid profiles of 202 coryneform and nocardioform bacteria were recorded by gas chromatography. Strains were grouped according to their profiles using mean linkage cluster analysis and similarity measures based on the correlation coefficient, the angular separation between vectors in a multidimensional space and the degree of overlap between superimposed traces. Comparisons using both real and hypothetical data showed the last of these measures to be the most effective. Strains were divided into two major groups, depending on whether they contained predominantly straight chain or iso- and anteiso-branched acids. The first group was divided into two subgroups according to the relative proportions of the characteristic acids present; one subgroup had six clusters containing the rhodococci, nocardiae, mycobacteria and caseobacters, and the other had two containing the xanthobacters and true corynebacteria. The second group was divided into one subgroup containing strains of Arthrobacter simplex, Arthrobacter tumescens and Arthrobacter duodecadis, and one having three clusters. One cluster from this latter subgroup contained cellulomonads, one contained brevibacteria and curtobacteria and one contained arthrobacters, oerskoviae and kurthiae. Identification to generic level by fatty acid composition alone may not be feasible, but fatty acid analysis coupled with morphological examination may be sufficient to identify Corynebacterium, Arthrobacter, Cellulomonas, Oerskovia, Brevibacterium, Caseobacter, Kurthia and the A. simplex/tumescens taxon. Distinction is not easy between Curtobacterium, Microbacterium and the diaminobutyric acid-containing coryneforms and between Rhodococcus, Mycobacterium and Nocardia.
\end{abstract}

\section{INTRODUCTION}

Lipid analyses are being used increasingly in bacterial taxonomy (see Lechevalier, 1977, for review). They are proving particularly helpful in the classification of the coryneform bacteria, where along with the major criteria of cell wall and DNA base composition, they provide valuable characters for the recognition of generic groups (see Keddie \& Cure, 1977, 1978; Minnikin et al., 1978; Keddie \& Bousfield, 1980 for reviews). The distribution and taxonomic significance of lipids in coryneform bacteria have been reviewed extensively by Minnikin et al. (1978) and further information is contained in the papers by Lechevalier et al. (1977), Kroppenstedt \& Kutzner (1978), Minnikin et al. (1979), Collins et al. $(1979,1980 a, b)$, Collins \& Jones $(1980,1981)$, Nesterenko et al. (1980) and Goodfellow et al. (1980). The long chain $\left(C_{10}\right.$ to $\mathrm{C}_{20}$ ) fatty acids of coryneform and related bacteria divide most of them into two broad groups (Minnikin et al., 1978). High proportions of straight chain saturated and monounsaturated acids occur in organisms having meso-diaminopimelic acid and arabinose in their cell wall (Corynebacterium sensu stricto, Caseobacter, Rhodococcus). Most other coryneform bacteria, regardless of cell wall composition, contain mainly iso- and anteiso-branched acids, but

Abbreviations: c.v., Coefficient of variation; DAB, 2,4-diaminobutyric acid; DAP, 2,6-diaminopimelic acid. 
Arthrobacter simplex and similar organisms have both branched and straight chain acids. The relative proportions of different fatty acids present vary considerably between members of these broad groups. Evidence suggests that this variation can be correlated to some extent with taxonomic groupings based on other criteria (Minnikin et al., 1978, 1979; Collins et al., 1980a, b, 1981; Collins \& Jones, 1980; Goodfellow et al., 1980). This, together with the fact that the reliable identification of many coryneform bacteria is difficult without recourse to some kind of cell wall analysis (Keddie \& Bousfield, 1980) suggests that the use of fatty acid profiles for preliminary identification is worth investigating.

Grouping of organisms according to fatty acid composition has been done subjectively by visual interpretation of profiles but, in a few cases, numerical taxonomic techniques have been applied. In these cases, similarity values have been obtained using variations of the correlation coefficient (Drucker, 1974; Jantzen et al., 1974a, b, 1975; Drucker et al., 1976; Bøe \& Gjerde, 1980), measures of the angular separation between two vectors in a multidimensional space (Drucker, 1974; Ikemoto et al., 1978) and measures of the Euclidean distance between paired objects (Bøe \& Gjerde, 1980). Cluster analysis, where done, was by the average linkage method (Sokal \& Michener, 1958). Drucker (1974) and Bøe \& Gjerde (1980) compared ways of measuring similarities between organisms based on fatty acid data, and concluded that algorithms derived from the correlation coefficient were the most useful, either with (Jantzen $e t$ $a l ., 1974 a, b, 1975$; Bøe \& Gjerde, 1980) or without (Drucker, 1974) logarithmic transformation of the original data. The application of numerical analysis to gas chromatographic data has been discussed by Drucker (1981).

In the present paper, both actual and hypothetical fatty acid data have been used to compare the effectiveness of similarity measures based on the correlation coefficient and the angular separation method with that of our own 'overlap' coefficient. In this last algorithm (described later) the percentage similarity between two organisms is defined simply as the degree of overlap between their superimposed fatty acid profiles, scaled to have the same total area of 100 . The most appropriate of the three algorithms appears to be the 'overlap' coefficient; therefore it has been used together with mean linkage clustering to analyse data for a large number of coryneform bacteria in an attempt to determine the value of fatty acid composition both as a taxonomic aid and as a primary identification criterion in this group of organisms.

\section{METHODS}

Strains and cultivation. The sources of the 202 strains are given in Figs 2 and 3. Most bacteria were grown on nutrient agar (Oxoid CM3) in Roux flasks for $7 \mathrm{~d}$ at $25^{\circ} \mathrm{C}$, killed by overnight incubation at room temperature with $25 \mathrm{ml} \mathrm{5 \%}(\mathrm{v} / \mathrm{v})$ formalin, collected by centrifuging at about $3200 \mathrm{~g}$ for $20 \mathrm{~min}$, washed twice with deionized water and freeze-dried. For Arthrobacter terregens NCIB 8909, 0.1\% (v/v) culture filtrate of Arthrobacter globiformis NCIB 8910 was added to the nutrient agar to provide the 'terregens factor' (Burton \& Lochhead, 1953). 'Curtobacterium psychrophilum' NCMB 2068 was grown at $15^{\circ} \mathrm{C}$.

Fatty acid designations. In the fatty acid designations, e.g. $18: 1$, the first number indicates the number of carbon atoms, and the second, the number of double bonds; 10-Me18 denotes the 10-methyl-branched acid 10methyloctadecanoic (tuberculostearic) acid.

Extraction and analysis of fatty acid methyl esters. Freeze-dried bacteria (about $50 \mathrm{mg}$ ) were methanolysed by refluxing for $1 \mathrm{~h}$ with $14 \% \mathrm{BF}_{3} /$ methanol reagent (Sigma; Metcalfe \& Schmitz, 1961). After cooling, cell debris was removed by filtration (Whatman no. 1 filter paper) and the fatty acid methyl esters were extracted with $3 \times$ $25 \mathrm{ml}$ amounts of the hexane fraction from petroleum (redistilled once). The pooled extracts were dried over anhydrous $\mathrm{Na}_{2} \mathrm{SO}_{4}$ to remove any moisture and residual methylating reagent, evaporated to dryness and redissolved in redistilled hexane fraction to a final volume of $0.25 \mathrm{ml}$. Extracts were analysed on a Pye 104 (Pye Unicam) or Packard 427 (Packard Instruments) gas chromatograph fitted with a flame ionization detector and a $3045 \mathrm{~mm}$ glass column ( $4 \mathrm{~mm}$ o.d.) with nitrogen as carrier gas (flow rate 24 to $40 \mathrm{ml} \mathrm{min} \mathrm{m}^{-1}$ ). Injection and oven temperatures were $220^{\circ} \mathrm{C}$; the detector temperature was $250^{\circ} \mathrm{C}$. The presence or absence of $20: 0$ acid in each extract was determined before the addition of $20: 0$ as internal standard $(0.1 \%$, w/v, in redistilled hexane fraction), after which extracts were dried again and redissolved to $0.25 \mathrm{ml}$ final volume in $\mathrm{CS}_{2}$. Extracts $(1 \mu \mathrm{l})$ were analysed using both non-polar 4\% (w/w) Apiezon $L$ on 80 to 100 mesh AW DMCS Chromosorb W and polar 5\% (w/w) FFAP on 80 to 100 mesh AW DMCS Chromosorb G (Perkin Elmer).

Fatty acid methyl esters were identified by comparing their relative retention times on the two columns with those of standards where available. In cases where standards were not available esters were identified by mass 
spectrometry in an extract of Arthrobacter simplex (NCIB 8929) and those in other organisms characterized as having the same chromatographic properties as the known esters in this organism. Fatty acid esters characterized in this way included 10-Me18 (tuberculostearic) acid, iso- and anteiso-15:1 and iso- and anteiso-17:1 acids. Further confirmation of the 10-Me18 (tuberculostearic) acid was obtained by reference to the profile of Mycobacterium tuberculosis (NCTC 7417), an organism where the chromatographic behaviour of this acid was known (D. E. Minnikin, personal communication). The amount of each acid present, expressed as a percentage of the total fatty acid $\left(\mathrm{C}_{10}\right.$ to $\left.\mathrm{C}_{20}\right)$ composition, was calculated from the ratio of its peak area to the total peak area using an integrator (Infotronics Model CRS 204).

Reproducibility of the chromatographic technique was determined by repeated injection $(\times 5)$ of identical samples of a mixture of standards. Reproducibility of profiles of the same strain was determined by analysing extracts of four cultures of $A$. simplex NCIB 8929 grown under identical conditions. In both cases the coefficient of variation was calculated for each peak.

Numerical analysis of fatty acid data. Hypothetical data designed to test the robustness of various similarity measures and the data of Bøe \& Gjerde (1980) were analysed in addition to data obtained in the present work. All data consisted of peak areas expressed as percentages of the total peak area of a trace, after peaks of area $<1 \%$ had been excluded. Similarities were calculated using the coefficients given below and clustering was achieved by the mean linkage method (Sokal \& Michener, 1958) using an IBM 1130 computer and programs written by one of us (G.L.S.) and H. R. Sanders of this Institute. The following similarity measures were used.

(1) $S_{\mathrm{C}}$, based on the correlation coefficient (Drucker, 1974; Jantzen et al., $1974 a, b$ ):

$$
S_{\mathrm{c}}(i, j)=50\left(1+r_{i, j}\right)
$$

where

$$
r_{i, j}=\sum_{k=1}^{p}\left(x_{i k}-\bar{x}_{i}\right)\left(x_{j k}-\bar{x}_{j}\right) / \sqrt{\sum_{k=1}^{p}\left(x_{i k}-\bar{x}_{i}\right)^{2}} \sqrt{\sum_{k=1}^{p}\left(x_{j k}-\bar{x}_{j}\right)^{2}}
$$

where $x_{i k}, x_{j k}$ are the percentage areas of the $k^{\text {th }}$ peak for the $i^{\text {th }}$ and $j^{\text {th }}$ organism respectively, and $x_{i}, \bar{x}_{j}$ are the mean percentage areas of all peaks for the $i^{\text {th }}$ and $j^{\text {th }}$ organism respectively.

(2) $S_{\mathrm{A}}$, based on the angle of separation of vectors (Drucker, 1974; Ikemoto et al., 1978):

$$
S_{\mathrm{A}}(i, j)=\sum_{k=1}^{p} \sqrt{x_{i k}} \sqrt{x_{j k}}
$$

where $x_{i k}, x_{j k}$ are as defined in (1). $S_{\mathrm{A}}$ divided by 100 is the cosine of the angle between the lines from the origin to two points, on a hypersphere of radius 10 , representing the $i^{\text {th }}$ and $j^{\text {th }}$ organism, respectively.

(3) $S_{\mathrm{O}}$, based on the degree of overlap of two superimposed traces, both scaled to have the same total area of 100 :

$$
S_{\mathrm{o}}(i, j)=100-\frac{1}{2} \sum_{k=1}^{p}\left|x_{i k}-x_{j k}\right|
$$

where $x_{i k}, x_{j k}$ are as defined in (1).

This 'overlap' coefficient attempts to mimic the way in which traces might be compared visually. In an intuitive sense, two traces which could be superimposed exactly would be considered completely similar, whereas two which showed no overlap would be completely dissimilar. Thus the similarity $S(i, j)$ could be defined as

$$
S(i, j)=\sum_{k=1}^{p} \min \left(x_{l k}, x_{j k}\right)
$$

which is equal algebraically to $S_{\mathrm{O}}(i, j)$ as expressed above if $\Sigma x_{i k}=\Sigma_{j k}=100$. The formula for $S_{\mathrm{O}}(i, j)$ also shows it to be a similarity measure corresponding to the 'city block' metric for distance.

Preparation of hydrolysates for cell wall analysis. Cell wall hydrolysates were prepared by Bousfield's modification (Keddie \& Cure, 1977) of the method of Boone \& Pine (1968), modified further as follows. Bacteria (about 5 to $10 \mathrm{mg}$ freeze-dried weight) were suspended in $2 \mathrm{ml} \mathrm{0.6} \mathrm{M-KOH}$ in glass Bijou bottles (about $6 \mathrm{ml}$ ) tightly closed with polypropylene screw caps. Suspensions were autoclaved at 1 atm $(101.3 \mathrm{kPa})$ for $5 \mathrm{~min}$ in a domestic pressure cooker, which was then plunged immediately into cold water. The cooled suspensions were diluted to $10 \mathrm{ml}$ with $2 \mathrm{M}-\mathrm{HCl}$ and centrifuged at $4000 \mathrm{~g}$ for $20 \mathrm{~min}$. Deposits were washed twice in $10 \mathrm{ml}$ amounts of deionized water and then resuspended in $0.5 \mathrm{ml} 10 \mathrm{M}-\mathrm{HCl}$. Water left in the deposit after decantation of the washings diluted this acid to about $6 \mathrm{M}$. Suspensions were divided into half in clean tightly capped Bijou bottles. Suspensions to be used for sugar analysis were diluted about $1: 2$ with deionized water and heated in an oven at $100^{\circ} \mathrm{C}$ for $2.5 \mathrm{~h}$. Suspensions for amino acid analysis were diluted about $1: 2$ with $6 \mathrm{M}-\mathrm{HCl}$ and heated at $100^{\circ} \mathrm{C}$, usually overnight, but always for at least $3.5 \mathrm{~h}$. All hydrolysates were then freeze-dried in a glass apparatus, water and $\mathrm{HCl}$ being trapped in a liquid nitrogen-cooled glass trap. Residues were then redissolved in about $0.05 \mathrm{ml} 10 \%$ $(\mathrm{v} / \mathrm{v}$, aq.) iso-propanol. 
Determination of cell wall diamino acid. Lysine, ornithine and 2,4-diaminobutyric acid (DAB) were determined by TLC of $10-15 \mu \mathrm{l}$ hydrolysate on glass plates precoated with $0.25 \mathrm{~mm}$ silica gel 60 (no. 5721 ; Merck) activated at $100^{\circ} \mathrm{C}$ for $1 \mathrm{~h}$. Chromatograms were developed by continuous elution for 5 to $6 \mathrm{~h}$ in the solvent system chloroform/methanol/ammonia (sp. gr. 0.88 )/water $(8: 8: 1: 3$, by vol.; Randerath, 1963), prepared as a biphasic system with the lower phase as irrigant. The meso and LL isomers of diaminopimelic acid (DAP) were determined by TLC of $10-15 \mu \mathrm{l}$ hydrolysate on aluminium plates precoated with $0.10 \mathrm{~mm}$ cellulose (no. 5552; Merck) (M. Dineen, personal communication) activated at $100^{\circ} \mathrm{C}$ for $1 \mathrm{~h}$. Chromatograms were developed for 3 to $4 \mathrm{~h}$ in the solvent system methanol/water/10 $\mathrm{M}-\mathrm{HCl} /$ pyridine $(32: 7: 1: 4$, by vol.; Hoare \& Work, 1955). All amino acid spots were located by spraying chromatograms with $0.3 \%(\mathrm{w} / \mathrm{v})$ ninhydrin in $96 \%(\mathrm{v} / \mathrm{v}$, aq. $) n$-butanol followed by heating at $100^{\circ} \mathrm{C}$ for a few minutes (Block et al., 1955).

Detection of cell wall arabinose. The presence of arabinose was determined by TLC of 10 to $15 \mu$ hydrolysate on activated cellulose plates. Chromatograms were developed twice in the same direction (about 45 min for each run) in the solvent system ethyl acetate/pyridine/water $(8: 2: 1$, by vol.; Block et al., 1955). Spots were located by spraying chromatograms with freshly prepared $0.1 \mathrm{M}$-p-anisidine $+0 \cdot 1 \mathrm{M}$-phthalic acid in $96 \%$ (v/v, aq.) ethanol followed by heating at $100^{\circ} \mathrm{C}$ for a few minutes (Block et al., 1955).

Determination of DNA base composition. The DNA base composition of selected strains was kindly determined by I. D. Ogden of the Torry Research Station. The DNA was prepared according to Gibson \& Ogden (1979) and the mol \% guanine + cytosine $(\% \mathrm{G}+\mathrm{C}$ ) was determined by the thermal denaturation method (Marmur \& Doty, 1962) using the equation of De Ley (1970).

Morphological examinations. The morphology of bacteria at various ages growing in situ on agar was examined by the method of Cure \& Keddie (1973), but observations were made directly from agar plates and not from blocks mounted on slides.

\section{RESULTS AND DISCUSSION \\ Comparison of similarity measures}

The three similarity measures based on the correlation coefficient $\left(S_{\mathrm{C}}\right)$, angular separation of vectors $\left(S_{\mathrm{A}}\right)$ and overlap of peaks $\left(S_{\mathrm{O}}\right)$ were compared initially using hypothetical rather than actual fatty acid data. This enabled us to test their robustness over a wide range of data and removed the temptation to select that coefficient which yielded a classification most resembling one predetermined by other criteria. Similarity measures based on Euclidean distance were not considered as they had proved unsatisfactory in preliminary studies with these types of data. If data were unscaled, similarities tended to be distorted by a single large peak; if data were scaled so that every peak had the same range, then peaks which were small for all organisms exerted excessive influence.

The hypothetical data are given in Table 1 and similarity values obtained from them using the $S_{\mathrm{C}}, S_{\mathrm{A}}$ and $S_{\mathrm{O}}$ coefficients are shown in Table 2. Dendrograms obtained using the mean linkage algorithm with each coefficient are shown in Fig. 1.

While all three measures would have given similarity values of $100 \%$ for a pair of identical profiles (not shown in Table 2), there was not always clear agreement between the $S_{\mathrm{C}}$ coefficient and the others on a criterion for a similarity value of 0 . Consider, for example, the pairs of profiles 1 and 2, 6 and 7 and 10 and 11 (Table 1). In each pair, the profiles could be said to be totally dissimilar, since neither had any peak in common with its partner, and indeed the $S_{\mathrm{A}}$ and $S_{\mathrm{O}}$ coefficients gave a similarity value of 0 for each pair (Table 2). However, the $S_{\mathrm{C}}$ coefficient gave a value of 0 only for pair 6 and 7 ; values for pairs 1 and 2 and 10 and 11 were $44 \%$ and $20 \%$, respectively. On the other hand profiles 5,8 and 9 were very similar in that all peaks had about the same relative area, and by the $S_{\mathrm{A}}$ and $S_{\mathrm{O}}$ coefficients each pair had a similarity of at least $98 \%$. By the $S_{\mathrm{C}}$ coefficient however, profiles 5 and 8 had a similarity of $0\left(S_{\mathrm{A}}=99.95 \%, S_{\mathrm{O}}=\right.$ $98.2 \%$ ), because a relatively high peak (albeit by a small amount) in one pattern corresponded to a relatively low peak in the other. Pairs 5 and 9 and 8 and 9 were given similarity values of only $50 \%\left(S_{\mathrm{A}}\right.$ and $\left.S_{\mathrm{O}}>99 \%\right)$ by the $S_{\mathrm{C}}$ coefficient. Conversely, when relatively high peaks coincided in a pair of profiles, as in 2 and 5 , the $S_{\mathrm{C}}$ coefficient yielded a similarity value of $100 \%$, even though the relative area of the coincident 'high' peaks was vastly different and despite the lack of similarity between the two profiles in respect of other peaks. Similarity values by the $S_{\mathrm{A}}$ and $S_{\mathrm{O}}$ coefficients were $33 \%$ and $11 \%$, respectively. Logarithmic transformation of the raw data 
Table 1. Hypothetical data used to test different similarity coefficients

\begin{tabular}{|c|c|c|c|c|c|c|c|c|c|c|c|}
\hline \multirow{2}{*}{$\begin{array}{c}\text { Organism } \\
\text { no. }\end{array}$} & \multirow[b]{2}{*}{ Peak no. .. } & \multicolumn{10}{|c|}{ Percentage composition } \\
\hline & & 1 & 2 & 3 & 4 & 5 & 6 & 7 & 8 & 9 & 10 \\
\hline 1 & & - & - & - & 100 & - & - & - & - & - & _- \\
\hline 2 & & - & - & -- & - & - & - & - & - & 100 & _- \\
\hline 3 & & $11 \cdot 1$ & $11 \cdot 1$ & $11 \cdot 1$ & $11 \cdot 1$ & $11 \cdot 1$ & $11 \cdot 1$ & $11 \cdot 1$ & $11 \cdot 1$ & - & $11 \cdot 1$ \\
\hline 4 & & 1 & 1 & 1 & 1 & 1 & 1 & 1 & 1 & 91 & 1 \\
\hline 5 & & 9.9 & 9.9 & 9.9 & 9.9 & 9.9 & 9.9 & 9.9 & 9.9 & 10.9 & 9.9 \\
\hline 6 & & 20 & 20 & 20 & 20 & 20 & - & - & - & - & - \\
\hline 7 & & - & - & - & - & - & 20 & 20 & 20 & 20 & 20 \\
\hline 8 & & $10 \cdot 1$ & $10 \cdot 1$ & $10 \cdot 1$ & $10 \cdot 1$ & $10 \cdot 1$ & $10 \cdot 1$ & $10 \cdot 1$ & $10 \cdot 1$ & $9 \cdot 1$ & $10 \cdot 1$ \\
\hline 9 & & $10 \cdot 0$ & $10 \cdot 0$ & $10 \cdot 0$ & 10.0 & 10.0 & 10.0 & $10 \cdot 0$ & $10 \cdot 0$ & 10.0 & 10.0 \\
\hline 10 & & 5 & 10 & 20 & 30 & 35 & - & - & - & - & - \\
\hline 11 & & - & - & 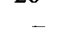 & - & - & 5 & 10 & 20 & 30 & 35 \\
\hline
\end{tabular}

Table 2. Values of similarity coefficients $S_{\mathrm{C}}, S_{\mathrm{A}}$ and $S_{\mathrm{O}}$ obtained from hypothetical data

\begin{tabular}{|c|c|c|c|c|c|c|c|c|c|c|c|}
\hline \multirow{2}{*}{$\begin{array}{c}\text { Organism } \\
\text { no. }\end{array}$} & \multirow{2}{*}{$\begin{array}{l}\text { Similarity } \\
\text { coefficient }\end{array}$} & \multicolumn{10}{|c|}{ Similarity coefficient obtained with organism no: } \\
\hline & & 1 & 2 & 3 & 4 & 5 & 6 & 7 & 8 & 9 & 10 \\
\hline \multirow{4}{*}{2} & $S_{\mathrm{C}}$ & 44 & & & & & & & & & \\
\hline & $S_{\mathrm{A}}$ & 0 & & & & & & & & & \\
\hline & $S_{\mathrm{O}}$ & 0 & & & & & & & & & \\
\hline & $S_{\mathrm{C}}$ & 56 & 0 & & & & & & & & \\
\hline \multirow[t]{3}{*}{3} & $S_{\mathrm{A}}$ & 33 & 0 & & & & & & & & \\
\hline & $S_{\mathrm{O}}$ & 11 & 0 & & & & & & & & \\
\hline & $S_{\mathrm{C}}$ & 44 & 100 & 0 & & & & & & & \\
\hline \multirow[t]{3}{*}{4} & $S_{\mathrm{A}}$ & 10 & 95 & 30 & & & & & & & \\
\hline & $S$ & 1 & 91 & 9 & & & & & & & \\
\hline & $S_{\mathrm{C}}$ & 44 & 100 & 0 & 100 & & & & & & \\
\hline \multirow[t]{3}{*}{5} & $S_{\mathrm{A}}$ & 31 & 33 & 94 & 60 & & & & & & \\
\hline & $S_{\mathrm{O}}$ & 10 & 11 & 89 & 20 & & & & & & \\
\hline & $S_{\mathrm{C}}$ & 67 & 33 & 67 & 33 & 33 & & & & & \\
\hline \multirow[t]{3}{*}{6} & $S_{\mathrm{A}}$ & 45 & 0 & 75 & 22 & 70 & & & & & \\
\hline & $S_{\mathrm{O}}$ & 20 & 0 & 56 & 5 & 49 & & & & & \\
\hline & $s_{\mathrm{C}}$ & 33 & 67 & 33 & 67 & 67 & 0 & & & & \\
\hline \multirow[t]{3}{*}{7} & $S_{\mathrm{A}}$ & 0 & 45 & 60 & 61 & 71 & 0 & & & & \\
\hline & & 0 & 20 & 44 & 24 & 50 & 0 & & & & \\
\hline & $S_{\mathrm{C}}$ & 56 & 0 & 100 & 0 & 0 & 67 & 33 & & & \\
\hline \multirow[t]{3}{*}{8} & $S_{\mathrm{A}}$ & 32 & 30 & 95 & 57 & 99.95 & 71 & 70 & & & \\
\hline & ${ }^{\mathrm{A}}$ & 10 & 9 & 91 & 18 & 98.2 & 50 & 49 & & & \\
\hline & $s_{\mathrm{C}}$ & 50 & 50 & 50 & 50 & 50 & 50 & 50 & 50 & & \\
\hline \multirow[t]{3}{*}{9} & $S_{\mathrm{A}}$ & 32 & 32 & 95 & 59 & 99.99 & 71 & 71 & 99.99 & & \\
\hline & & 10 & 10 & 90 & 19 & $99 \cdot 1$ & 50 & 50 & $99 \cdot 1$ & & \\
\hline & $S_{\mathrm{C}}$ & 76 & 37 & 63 & 37 & 37 & 89 & 11 & 63 & 50 & \\
\hline \multirow[t]{3}{*}{10} & $S_{\mathrm{A}}$ & 55 & 0 & 71 & 21 & 67 & 95 & 0 & 68 & 67 & \\
\hline & & 30 & 0 & 48 & 5 & 45 & 75 & 0 & 45 & 45 & \\
\hline & $D_{\mathrm{C}}$ & 37 & 76 & 24 & 76 & 76 & 11 & 89 & 24 & 50 & 20 \\
\hline \multirow[t]{2}{*}{11} & $S_{\mathrm{A}}$ & 0 & 55 & 53 & 68 & 68 & 0 & 95 & 67 & 67 & 0 \\
\hline & $(3)$ & 0 & 30 & 37 & 34 & 46 & 0 & 75 & 44 & 45 & 0 \\
\hline
\end{tabular}

(see e.g. Bøe \& Gjerde, 1980) would reduce to some extent the distorting effect of large peaks on the $S_{\mathrm{C}}$ coefficient, but in essence the above arguments would still apply. Therefore the comparison of fatty acid profiles using similarity measures based on the correlation coefficient should be regarded with caution, since such measures can prove unreliable in some situations (see below).

Although the $S_{\mathrm{A}}$ and $S_{\mathrm{O}}$ coefficients agreed more with each other than did either with the $S_{\mathrm{C}}$ coefficient, the $S_{\mathrm{A}}$ coefficient had the disadvantage of moving rather slowly away from $100 \%$ as differences between profiles increased. Thus the visually highly similar patterns 5 and $8\left(S_{\mathrm{O}}=\right.$ 


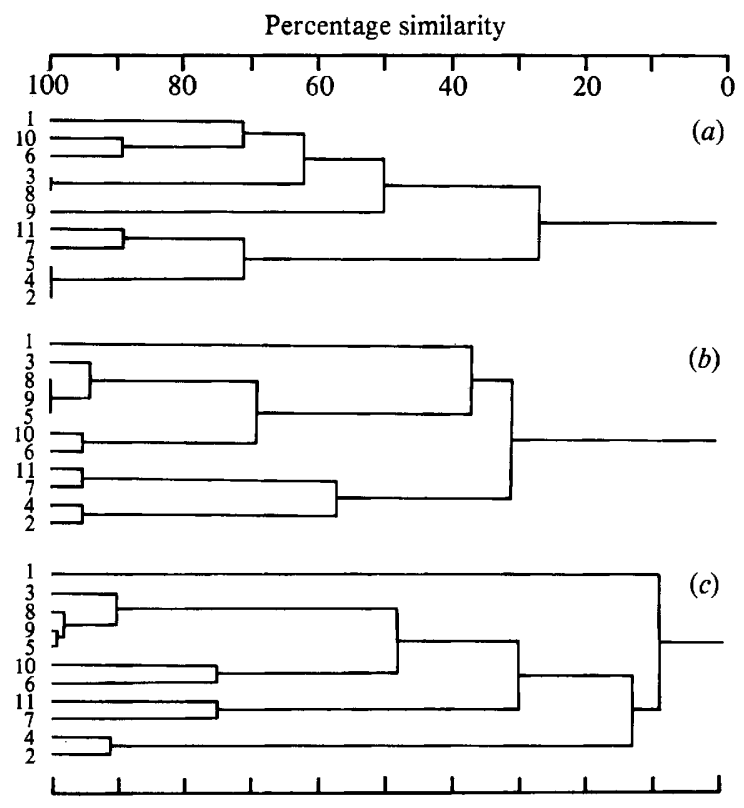

Fig. 1. Clustering of hypothetical organisms (Table 2) using the mean linkage algorithm with (a) $S_{\mathrm{C}}$, (b) $S_{\mathrm{A}}$ and $(c) S_{\mathrm{O}}$ coefficients.

$98.2 \%)$ were recorded as virtually identical by the $S_{\mathrm{A}}$ coefficient $\left(S_{\mathrm{A}}=99.95 \%\right)$ and, more strikingly, the moderately similar patterns 6 and $10\left(S_{\mathrm{O}}=75 \%\right)$ were given a similarity value of $95 \%$. For this reason, the $S_{\mathrm{o}}$ coefficient seemed more appropriate than the $S_{\mathrm{A}}$ for estimating similarity between fatty acid profiles. Nevertheless, despite the higher similarity values given by the latter, the $S_{\mathrm{O}}$ and $S_{\mathrm{A}}$ coefficients yielded structurally similar clusters (Fig. $1 b, c$ ) which often contrasted with those based on the $S_{\mathrm{C}}$ coefficient (Fig. 1a). Although the above considerations led us to select the $S_{\mathrm{O}}$ coefficient as the most appropriate for the analysis of our coryneform data, we also compared the effect of the $S_{\mathrm{A}}$ and $S_{\mathrm{C}}$ coefficients on the same data. The dendrogram derived from the $S_{\mathrm{O}}$ analysis, simplified and divided into two parts for convenience of presentation, is shown in Figs 2 and 3; that derived from the $S_{\mathrm{A}}$ analysis broadly resembled it in structure although certain strains in subgroups A and B were transposed and subgroup C was placed as an outlier of Group 1 (see below). However, as expected, similarity values were considerably higher in the $S_{\mathrm{A}}$ run and some clusters, particularly $k$ and $l$ in Group 2, were poorly defined. In the $S_{\mathrm{C}}$ analysis, this tendency was exaggerated to extremes and there occurred several of the distortions demonstrated above with hypothetical data. Thus similarity values were very high, mainly as a result of coincident 'large' peaks (cf. hypothetical pair 2 and 5 in Tables 1 and 2) and the constituent clusters in subgroup D were not resolved, since similarity values between strains were almost all 97 to $100 \%$. Also the two strains of $A$. simplex were separated from Arthrobacter tumescens (subgroup C) because their relatively large 10-Me18 peaks (see below) gave them an unduly high similarity with the rhodococci. The subgroups and clusters in Group 1 were recognizable, although again at very high similarity levels $(95$ to $100 \%)$.

In the $S_{\mathrm{O}}$ analysis, the main groups 1 and 2 joined at a similarity level slightly above 0 , whereas in the $S_{\mathrm{A}}$ analysis, this occurred at about $11 \% \mathrm{~S}$ and in the $S_{\mathrm{C}}$ run, at almost $50 \% \mathrm{~S}$. This was accounted for by the relatively large number of coincident 'zero' peaks, despite the virtual noncoincidence of all major peaks (cf. hypothetical pair 1 and 2 in Tables 1 and 2).

When the three coefficients were tested (without logarithmic transformation) against the data of Bøe \& Gjerde (1980) for Gram-negative organisms, similar classifications were obtained, but at differing similarity levels. Thus in this case the $S_{\mathrm{C}}$ coefficient performed satisfactorily, largely because the data of Bøe \& Gjerde presented fewer extreme comparisons than did ours. 
It is clear from the results with the hypothetical data, our own real data and those of Bøe \& Gjerde that the robustness of a similarity measure based on the correlation coefficient depends very much on the spread of the data to which it is applied, and that it may not be suitable for all groups of organisms.

\section{Fatty acid analyses}

Reproducibility. The coefficient of variation (c.v.) for peak areas of individual standards was $<0.5 \%$ for all except the $18: 1$ standard (c.v. $=0.6 \%$ ). The c.v. for peak areas in profiles of four cultures of $A$. simplex NCIB 8929 grown under identical conditions was $<6 \%$ for all peaks except 16:0 (c.v. $=9 \%$ ), 10-Mel8 (c.v. $=9.4 \%$ ) and $18: 0$ (c.v. $=11.8 \%$ ) acids.

Resolution of peaks. Resolution of iso- and anteiso-13:0, iso- and anteiso-15:0, iso- and anteiso$15: 1$, iso- and anteiso- $17: 0$ and iso- and anteiso-17:1 acids, respectively, was not always unequivocal. Therefore to avoid possible invalid comparisons in the statistical analyses, iso and anteiso peak areas were combined for these acids, even when full separation was obtained. In most cases this had little effect on clustering, and will be discussed in more detail later.

Comparison with previous data. Results of fatty acid analyses for many coryneform bacteria are given by Collins (1978) and by Minnikin et al. (1979), Collins et al. (1980a, b), Collins \& Jones (1980) and Goodfellow et al. $(1978,1980)$. After combining the iso and anteiso components of $C_{15}$ and $\mathrm{C}_{17}$ acids, we compared a cluster analysis ( $S_{\mathrm{O}}$ coefficient) on the pooled data from these reports (for convenience referred to subsequently in the present paper as the 'Collins $e t$ al. pooled data') with that done on our own data, and found the two cluster diagrams to be very similar. We also calculated similarity values between our results and those of the above authors where the same strains had been examined. Here, similarities varied considerably from $>90 \%$ for many corynebacteria to about $50 \%$ for the kurthiae (see below). Thus while the amounts of various acids found in the same or similar strains by the above authors and ourselves sometimes appeared to differ considerably, the grouping of strains and the relationships between groups were very much the same in both cases. This simple exercise clearly demonstrates the value of numerical analysis in comparing fatty acid data sets from different laboratories.

Fatty acid composition of strains. The fatty acid composition of strains is summarized in Table 3. The complete data have been deposited with the British Library Lending Division, Boston Spa, Yorkshire, U.K. as Supplementary Publication No. SUP 20814 (14 pp.). (Copies may be obtained from the BLL on demand; requests should be accompanied by prepaid coupons, held by many university and technical libraries and by the British Council.) As expected, the organisms were divided into two major groups on the basis of their fatty acid composition: those containing high proportions of straight chain and sometimes 10-methyl-branched acids (Group 1, Fig 2) and those containing mainly iso- and anteiso-branched acids (Group 2, Fig 3) (see e.g. Minnikin et al., 1978). These groups corresponded to the well recognized division of coryneform and nocardioform bacteria into those having mycolic acids and meso-DAP and arabinose in their cell walls (Group 1) and those lacking mycolic acids and arabinose and often having diamino acids other than meso-DAP (Group 2) (see e.g. Keddie \& Cure, 1977). The only exceptions were the inclusion in Group 1 of cluster $g$ containing the non-mycolic acid-containing Xanthobacter flavus ('Mycobacterium flavum') and Xanthobacter autotrophicus ('Corynebacterium autotrophicum'), neither of which are coryneform bacteria. Both are pleomorphic but Gramnegative and were originally included in this study because their true taxonomic position was uncertain. They were classified in the genera Mycobacterium (Federov \& Kalininskaya, 1961) and Corynebacterium (Baumgarten et al., 1974) but were transferred to Xanthobacter by Weigel et al. (1978) and Malik \& Claus (1979), respectively. We have left these organisms in the dendrogram (Fig. 2) to emphasize the importance of keeping the interpretation of fatty acid analyses in its proper taxonomic perspective. Fatty acid profiles, not overall phenotypes, are being compared and there is fundamentally no reason why taxonomically very different organisms should not have similar fatty acid compositions. 


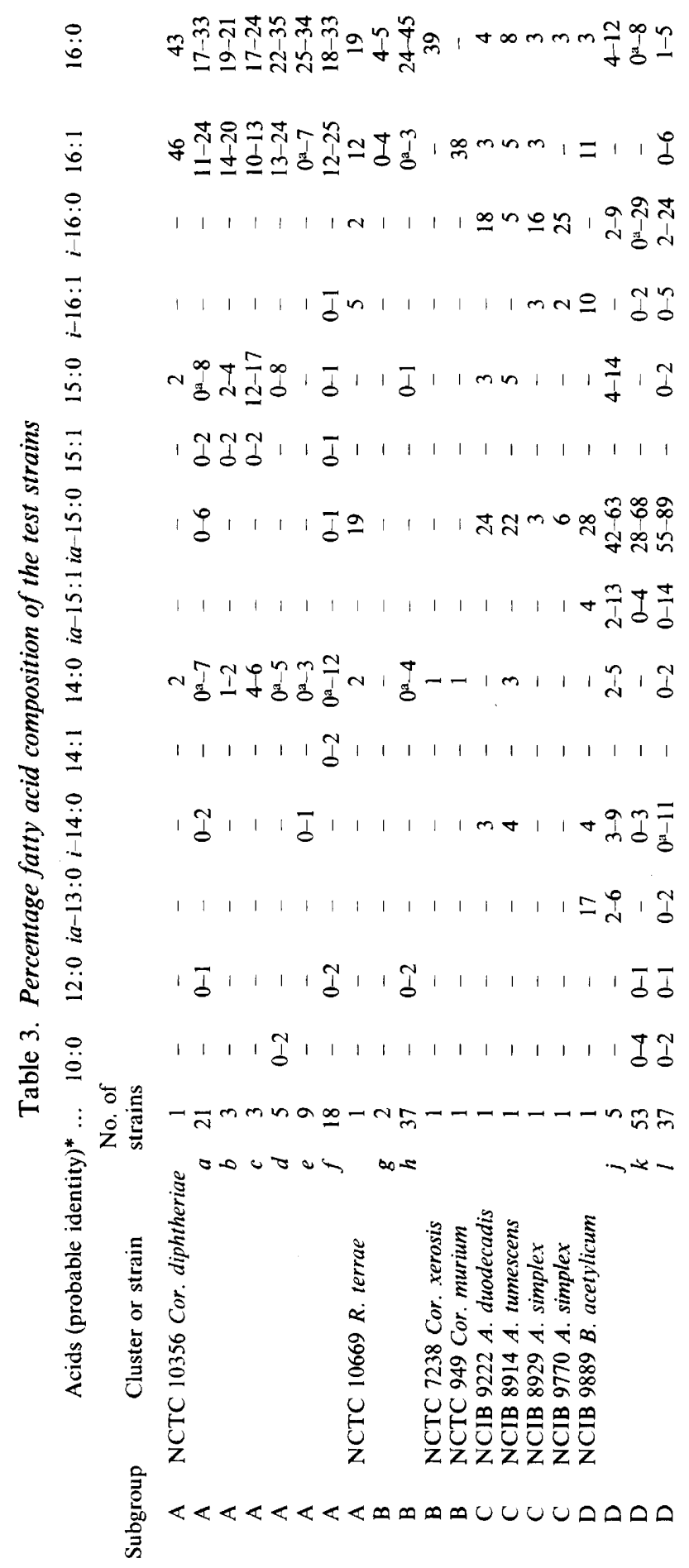




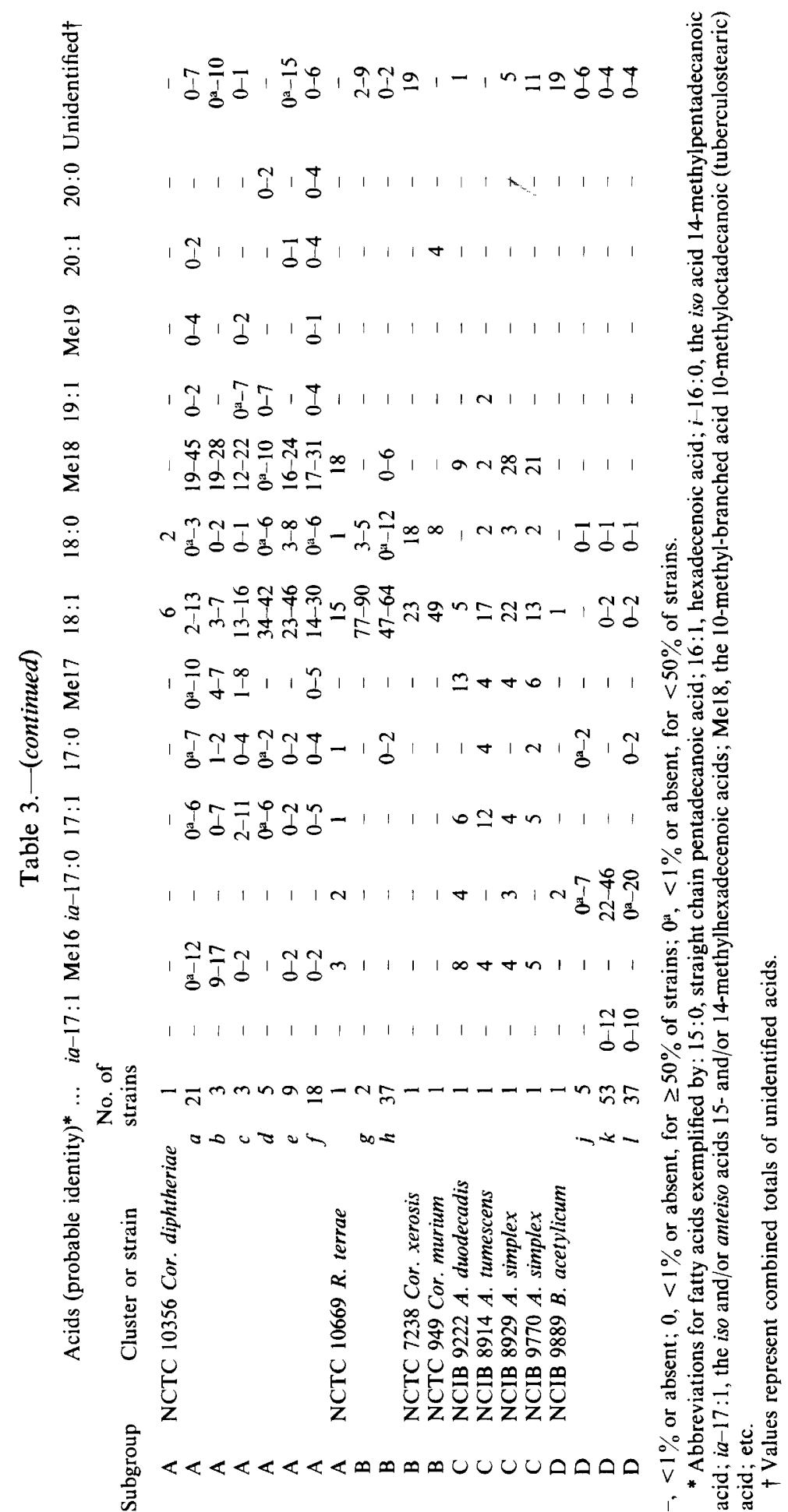




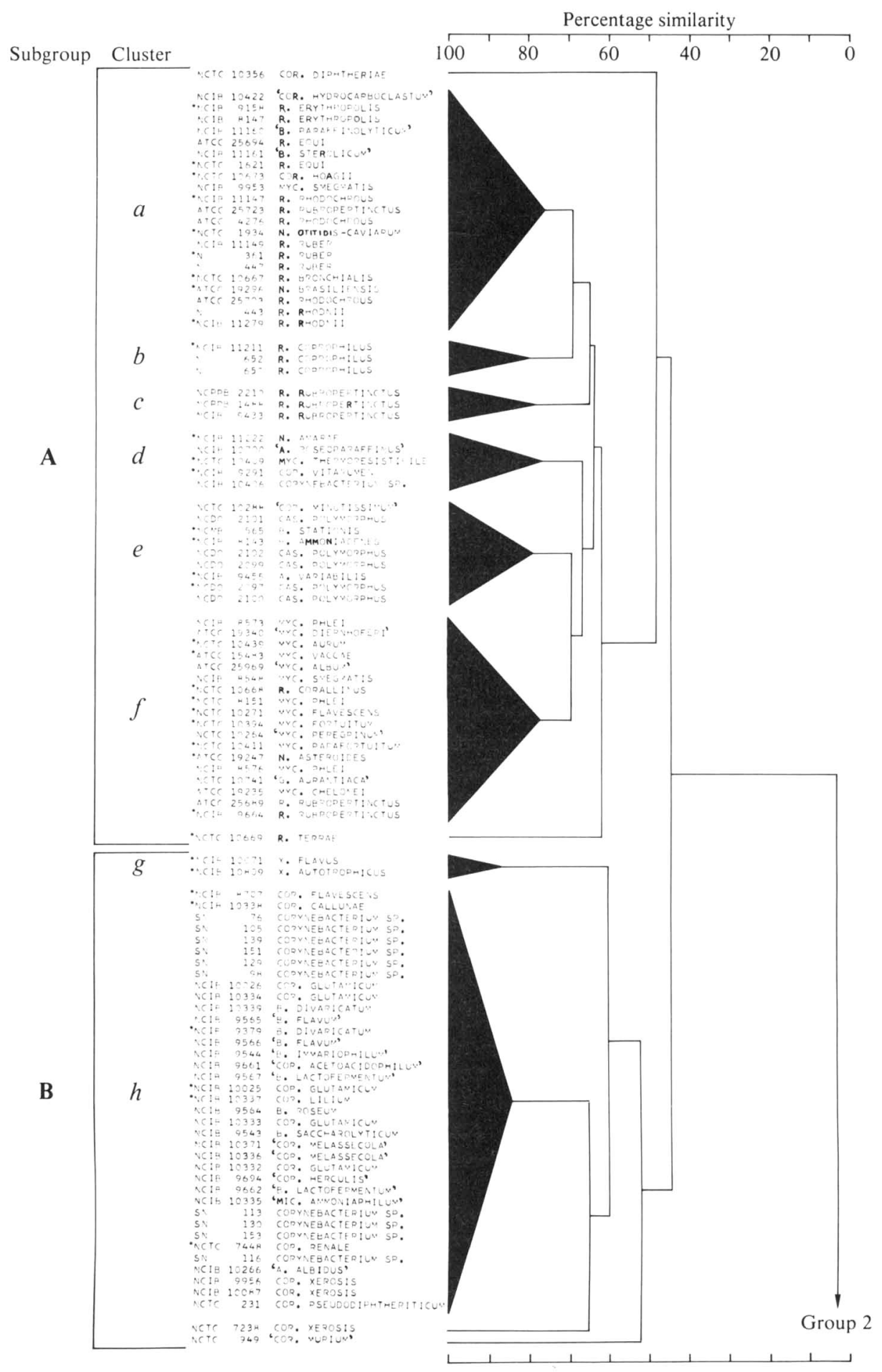

Fig. 2. Clustering of Group 1 strains with the $S_{O}$ coefficient and mean linkage algorithm. See footnote to Fig. 3 for abbreviations. 


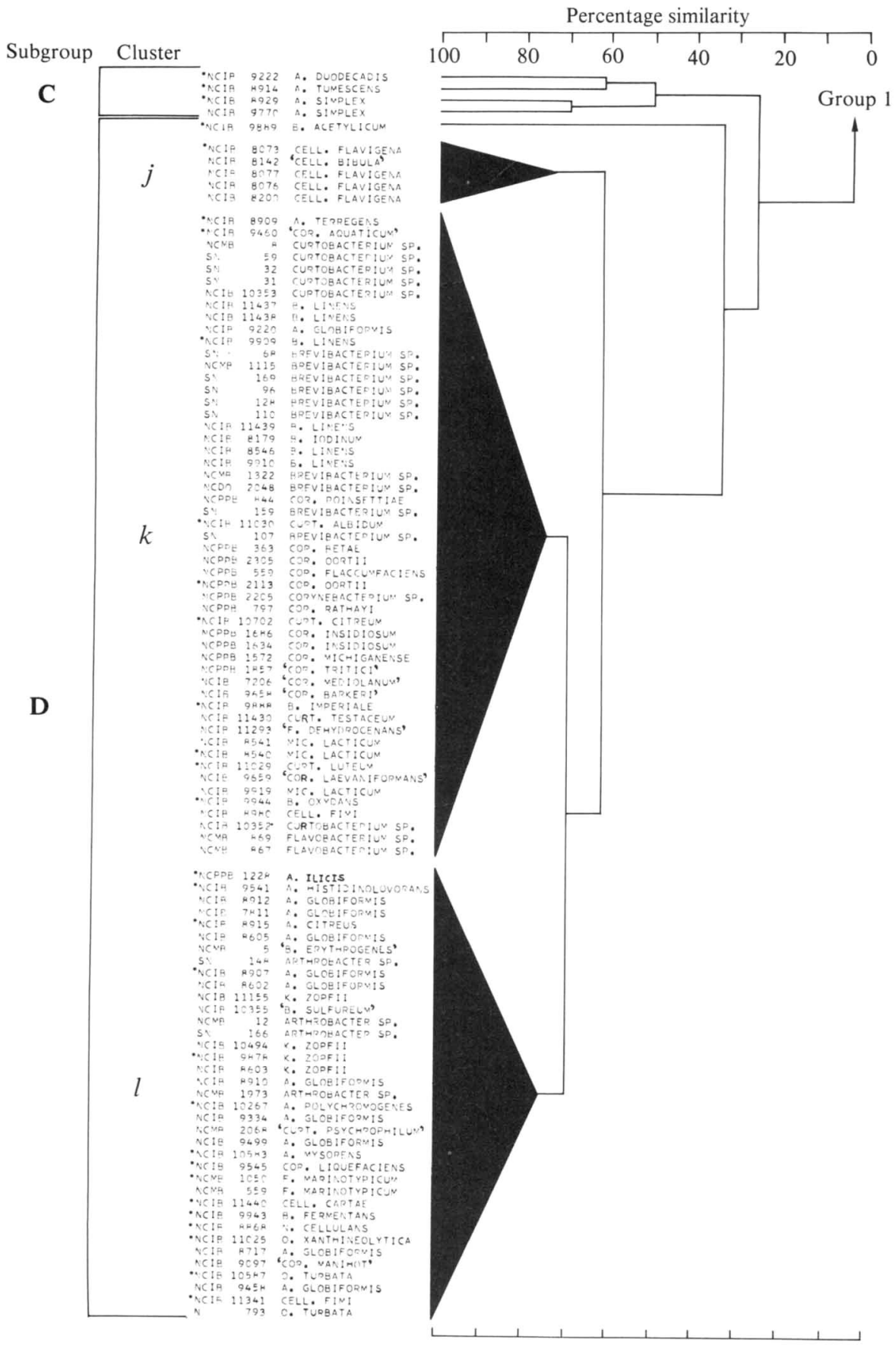

Fig. 3. Clustering of Group 2 strains with the $S_{\mathrm{O}}$ coefficient and mean linkage algorithm. Type strains are marked with an asterisk $\left(^{*}\right)$. Names not included in the Approved Lists of Bacterial Names (Skerman et al., 1980) are given in quotation marks. See text for abbreviations of generic names. Strains bearing culture collection prefixes were received from those collections. NCIB, National Collection of Industrial Bacteria, Aberdeen, U.K.; NCMB, National Collection of Marine Bacteria, Aberdeen, U.K.; NCTC, National Collection of Type Cultures, London, U.K.; NCPPB, National Collection of Plant Pathogenic Bacteria, Harpenden, U.K.; NCDO, National Collection of Dairy Organisms, Reading, U.K.; ATCC, American Type Culture Collection, Rockville, Md., U.S.A. Strains bearing N prefixes were received from Dr M. Goodfellow, University of Newcastle-upon-Tyne, England, U.K. Strains bearing SN prefixes are marine strains from the collection of I. J. Bousfield. 
Group 1 was divided into subgroups A and B. In the former, $16: 0,16: 1,18: 1$ and 10-Me18 acids predominated. This subgroup was divided into six clusters $(a$ to $f$ ) and two outlying strains based on quantitative differences. Subgroup B contained two clusters, $g$ and $h$. Cluster $g$ (discussed above) was characterized by the marked predominance of a single acid, $18: 1$. This acid predominated in cluster $h$ too, but high proportions of $16: 0$ also occurred.

Group 2 was divided into subgroups $C$ and $D$. The former comprised four strains which differed from all other Group 2 strains in having 10-methyl-branched acids in addition to isoand anteiso-branched acids and more than very small amounts of $18: 1$. Subgroup D separated into three clusters $(j$ to $l$ ) and one outlying strain according to quantitative differences in fatty acid composition.

Although clusters $a$ to $l$ can be separated with reasonable confidence, they frequently do not correspond to presently recognized taxa.

Subgroup A. Clusters $a, b, c$ and $f$ contained all but three of the named rhodococci, mycobacteria and nocardiae studied, although separation of these groups was not entirely clear. Thus Mycobacterium smegmatis NCIB 9953, Nocardia brasiliensis ATCC 19296 and Nocardia otitidis-caviarum NCTC 1934 fell into cluster $a$, which otherwise comprised named rhodococci and strains considered to belong to, or at least to have affinities with the genus Rhodococcus (see e.g. Bousfield \& Goodfellow, 1976; Keddie \& Cure, 1977, 1978; Minnikin et al.. 1978; Collins et al., 1982). Cluster $f$ contained almost all the mycobacteria studied, but also Nocardia asteroides ATCC 19247, 'Gordona aurantiaca' NCTC 10741 and three rhodococci. Clusters $b$ and $c$ contained only rhodococci, the latter comprising three strains transferred from the genus Corynebacterium by Goodfellow \& Alderson (1977). Clusters $d$ and $e$ were unusual in subgroup A in having low levels of 10-Me18 and 16:1 acids, respectively. In these respects they resembled the corynebacteria in subgroup B; indeed examination of the complete $S$-matrix showed high similarities between individual strains in clusters $d$ and $e$ and subgroup B. The equivocal similarities of the profiles of cluster $d$ and $e$ strains are matched by other ambiguities in the taxonomic relationships of some of these organisms. Thus Arthrobacter variabilis NCIB 9455, Corynebacterium vitarumen NCIB 9291 and Caseobacter polymorphus NCDO 2097 and 2099 to 2102 resemble the rhodococci in their DNA base composition (65 to $69 \mathrm{~mol} \% \mathrm{G}+\mathrm{C}$; Yamada \& Komagata, 1970; Crombach, 1978; Lanéelle et al., 1980; the present work) but have mycolic acids of the Corynebacterium type (Keddie \& Cure, 1977; Crombach, 1978; Lanéelle et al. 1980; Collins et al., 1982). The mycolic acid chain lengths of 'Arthrobacter roseoparaffineus' NCIB 10700 overlap those of Corynebacterium and Rhodococcus (Collins et al., 1982), but again the DNA base composition of this strain ( $70 \mathrm{~mol} \% \mathrm{G}+\mathrm{C}$; the present work) suggests a closer relationship with the latter. On the other hand, DNA base composition (51 to $57 \mathrm{~mol} \% \mathrm{G}+\mathrm{C}$; Bouisset et al., 1963; Bowie et al., 1972; Yamada \& Komagata, 1970) and mycolic acid chain length (Minnikin et al., 1978; Collins et al., 1982) suggest that Brevibacterium stationis NCMB 565, Brevibacterium ammoniagenes NCIB 8148 and 'Corynebacterium minutissimum' NCTC 10288 belong with the true corynebacteria, despite their placement here in subgroup A, which as with other cluster $e$ strains, is largely a consequence of their 10-Me18 acid content.

The uncertain affiliations of many of the above strains highlight the difficulties of separating and defining the genera Corynebacterium and Rhodococcus on what are essentially continuously variable quantitative criteria. While we agree with Keddie \& Bousfield (1980) and Collins et al. (1982) that the taxonomic position of Caseobacter is uncertain and that its relationships to Corynebacterium and Rhodococcus need clarifying, we nevertheless feel that the genus serves a useful purpose at present in accommodating some organisms which appear to be intermediate between these genera. From this point of view, the transfer of $A$. variabilis to the genus Caseobacter might be considered.

Nocardia amarae NCIB 11222 and Mycobacterium thermoresistibile NCTC 10409 fell into cluster $d$ mainly because of their low 10-Me18 acid content. Although other evidence indicates that these organisms to some extent are not typical nocardiae (Orchard et al., 1977; Goodfellow et al., 1982) or mycobacteria (Tsukamura et al., 1979), respectively, there is none to suggest that they are any more related to the true corynebacteria than are other nocardiae and mycobacteria. 
Of the two outlying strains in subgroup A, Rhodococcus terrae NCTC 10699 differed from all other Group 1 strains in having almost $30 \%$ of iso- and anteiso-branched acids. Such acids occurred in very few other Group 1 strains, and even then in very small amounts.

In the $S_{\mathrm{A}}$ analysis Corynebacterium diphtheriae NCTC 10356 was an outlier in subgroup B, at first sight a more logical placement from a taxonomic point of view, but the full $S_{\mathrm{O}}$ and $S_{\mathrm{A}}$ similarity matrices showed that in either analysis bias in favour of allocation to one subgroup or the other was marginal. This strain was distinguished from all others in Group 1 by its remarkably high level of $16: 1$. Similarly large amounts of $16: 1$ have been found in other strains of Cor. diphtheriae, Corynebacterium pseudotuberculosis and 'Corynebacterium ulcerans' (Fulco et al., 1964; Alshamaony et al., 1977; Collins, 1978). Indeed the analysis of the 'Collins et al. pooled data' showed these three species as a discrete cluster, associated with the equivalent of subgroup A at about the same level as Cor. diphtheriae in the present work, but likewise distinct from the saprophytic corynebacteria.

Most previous reports on the fatty acid composition of mycobacteria, nocardiae and rhodococci (for reviews see Minnikin \& Goodfellow, 1976, 1980; Lechevalier, 1977; Minnikin et $a l ., 1978)$ do not give the detailed proportions of different acids. Where we have been able to compare our results with other work, agreement has been generally very good (Bordet \& Michel, 1963; Pommier \& Michel, 1973; Alshamaony et al., 1977; Collins, 1978), given the differences in growth media and conditions. However, some of our results differ from those of Bowie et al. (1972) who did not report the presence of 10-Me18 in any of the strains they examined. A further notable discrepancy is the difference between our result and that of Goodfellow et al . (1978) for the type strain of ' $G$. aurantiaca', NCTC 10741 . We found roughly equal proportions of $16: 0$, $18: 1$ and 10-Me18 acids in this strain, whereas Goodfellow et al. (1978) reported a marked predominance of $16: 0$. However, the results these authors obtained for several other strains of 'G. aurantiaca' were on the whole more similar to ours for NCTC 10741.

Subgroup B. Apart from X. flavus and X. autotrophicus (cluster $g$ ) which are discussed above, subgroup $B$ consisted entirely of strains bearing a variety of names but now all considered to belong to the genus Corynebacterium sensu stricto (see e.g. Bousfield \& Goodfellow, 1976; Keddie \& Cure, 1977, 1978; Minnikin et al., 1978; Collins et al., 1979, 1982; Barksdale et al., 1979; Keddie \& Bousfield, 1980). However, the fatty acid profiles of these corynebacteria differed in several respects from that of the type species of the genus, Cor. diphtheriae (see above). Cluster $h$ consisted mainly of industrial strains, many of which probably belong to the single species Corynebacterium glutamicum (Abe et al., 1967), together with a few animal-associated corynebacteria. Also included were several strains of marine origin (denoted by the prefix SN), considered by Bousfield (1978) to belong to Corynebacterium sensu stricto, but unusual among the true corynebacteria in being strict aerobes (Keddie \& Cure, 1977; Keddie, 1978).

Of the two outlying strains in subgroup B, Corynebacterium xerosis NCTC 7238 had much less $18: 1$ than other strains. 'Corynebacterium murium' NCTC 949 differed sharply from other strains in having no $16: 0$ and a predominance of $16: 1$ acids.

There are few published data with which to compare our results for subgroup B strains, but fatty acid profiles of a number of these strains are given by Collins (1978). In general, our results show excellent agreement with his and indeed computation of his and our data for the cluster $h$ corynebacteria yielded similarities between them of about $90 \%$. However, our result for Corynebacterium flavescens ('Microbacterium flavum') NCIB 8707, a strain not examined by Collins, differed from that of Barksdale et al. (1979), who reported fairly high proportions $(22 \%)$ of branched chain $\mathrm{C}_{15}$ acids. We did not find more than very small amounts of branched acids in any of the true corynebacteria, or indeed (other than 10-methyl-branched) in any Group 1 strains with the exception of $R$. terrae NCTC 10669.

Subgroup $C$. The taxonomic relationships of subgroup C strains with other coryneforms are obscure and the fatty acid analyses shed little further light, other than to underline this point. Arthrobacter simplex and $A$. tumescens have LL-DAP as the cell wall diamino acid and are not considered to be legitimate members of the genus Arthrobacter (see e.g. Yamada \& Komagata, 1972; Keddie \& Cure, 1978; Minnikin et al., 1978), which have lysine, but as Keddie \& Cure 
(1978) and Keddie \& Bousfield (1980) have pointed out, no suitable alternative genus exists at present. Arthrobacter duodecadis has lysine in its cell wall but in other respects differs from the true arthrobacters (Keddie \& Cure, 1977). The fatty acid profiles of subgroup C strains reinforce the case for their separation from the genus Arthrobacter and indeed these organisms are singular among non-mycolic acid-containing coryneforms in having 10-methyl-branched (notably 10Me18) acids and significant amounts of straight chain acids. Findings similar to ours were reviewed by Minnikin $e t$ al. (1978) for $A$. simplex and $A$. tumescens. In this respect, subgroup C strains resembled to some extent the nocardioform organisms of subgroup $A$, and in fact the $S_{\mathrm{A}}$ analysis placed subgroup $C$ as an outlier in Group 1, largely because of the presence of straight chain and 10-methyl-branched acids. The menaquinone composition of $A$. simplex and $A$. tumescens has also been reported to be similar in part to that of the nocardiae (Collins et al., 1979).

Subgroup D. Cluster $j$ consisted of five Cellulomonas strains. We did not detect such high proportions of straight chain acids in cluster $j$ strains as did Minnikin et al. (1979) in the cellulomonads they examined, but we agree to some extent that the occurrence of branched $C_{13}$ acids in cellulomonads might be useful in distinguishing them from the oerskoviae. However, we did not detect such acids in Cellulomonas fimi NCIB 11341, a strain not examined by Minnikin $e t$ al. (1979), nor did we find any straight chain acids other than the 16:0 common to most subgroup D strains. In these respects, the profile of Cell. fimi NCIB 11341 resembled those of the oerskoviae, with which this strain clustered. Nevertheless, the other properties of Cell. fimi NCIB 11341, including its cell wall composition (ornithine is the diamino acid), suggest that it is correctly classified in the genus Cellulomonas (unlike Cell. fimi NCIB 8980, which is probably a curtobacterium; see below and Keddie \& Bousfield, 1980). More contentious, however, is the question of whether Cellulomonas and Oerskovia should be retained as separate genera. There are many similarities between them (Jones \& Bradley, 1964; Bousfield, 1972; Jones, 1975; Minnikin et al., 1979; Collins et al., 1979; Stackebrandt et al., 1980) and while several workers do not question their separate status (see e.g. Jones, 1975; Keddie \& Cure, 1977, 1978; Minnikin et al., 1978; Keddie \& Bousfield, 1980; M. D. Collins, personal communication), a case has been put forward for their amalgamation on molecular grounds (Stackebrandt et al., 1980).

Most strains in cluster $k$ belonged to or have been considered possibly to belong to the genera Brevibacterium (as redefined by Collins et al., 1980b) or Curtobacterium. Thus, in addition to strains of the two named species of Brevibacterium sensu novo, Brevibacterium linens and Brevibacterium iodinum, cluster $k$ contained several strains having the characteristics, particularly the cell wall composition (meso-DAP, no arabinose), of the genus and tentatively identified as Brevibacterium spp. (Bousfield, 1978; Sharpe et al., 1976; 1977; the present work). All the named curtobacteria except 'Curt. psychrophilum' were recovered in cluster $k$, together with strains having many of the properties of curtobacteria and considered to be possible candidates for the genus (Corynebacterium betae, Corynebacterium flaccumfaciens, Corynebacterium poinsettiae, Corynebacterium oortii, 'Corynebacterium barkeri', Brevibacterium oxydans, $A$. terregens, Cell. fimi NCIB 8980 and various ‘Curtobacterium spp.’; Yamada \& Komagata, 1972; Jones, 1975; Keddie \& Cure, 1977, 1978; Bousfield, 1978; Minnikin et al., 1978; Collins et al., $1980 a$ ). However, in some respects a genus containing all these strains might be somewhat heterogeneous (Yamada et al., 1976; Collins et al., 1980a) and in fact Collins \& Jones (1981) suggest that on the basis of menaquinone composition, Curtobacterium testaceum (also suggested by Collins et al., 1980a) and 'Cor. barkeri' do not belong to the genus Curtobacterium. This view is supported, for Curt. testaceum at least, by DNA homology studies (Suzuki et al., 1981).

Also present in cluster $k$ were several strains containing DAB in their cell wall (Yamada \& Komagata, 1972; Schleifer \& Kändler, 1972; Keddie \& Cure, 1977; the present work) and for which no taxonomic niche exists at present ('Corynebacterium aquaticum', 'Corynebacterium tritici', Corynebacterium michiganense, Corynebacterium rathayi, Corynebacterium insidiosum, 'Flavobacterium dehydrogenans' and Flavobacterium spp. NCMB 867 and 869). Cluster $k$ also contained three strains of Microbacterium lacticum, a lysine-containing species considered to be a distinct taxonomic entity (Keddie \& Cure, 1978) and possibly the nucleus of a redefined genus 
Microbacterium (Jones, 1975). Also present were Brevibacterium imperiale NCIB 9888, the lipids of which were shown by Collins (1978) to be similar to those of $M$. lacticum, and 'Corynebacterium laevaniformans' NCIB 9659. These two strains have been shown to be similar to $M$. lacticum phenetically (Bousfield, 1972; Jones, 1975), in peptidoglycan type (Schleifer \& Kändler, 1972) and in their unusual menaquinone composition (Collins \& Jones, 1981). Indeed, despite differences in the cell wall diamino acid, most of the strains in cluster $k$, except for the true brevibacteria, have been shown to have the same unusual peptidoglycan structure (Schleifer \& Kändler, 1972). Our results do not contradict suggestions (Keddie \& Cure, 1978; Minnikin et al., 1978; Collins \& Jones, 1980) that there may be a relationship between the curtobacteria, the DAB-containing coryneforms and $M$. lacticum, although on the basis of DNA homology studies, Suzuki et al. (1981) believe otherwise. Certainly these groups cannot be reliably distinguished from each other by their fatty acid composition. However, nor can they be reliably distinguished on this basis from the true brevibacteria, which in most other respects are quite different organisms, although in many cases differences in the relative amounts of $C_{15}$ and $C_{17}$ acids are a useful guide.

The fatty acid profile of $A$. globiformis (atrocyaneus) NCIB 9220 resembled those of the curtobacteria and brevibacteria, resulting in its recovery in cluster $k$, although in other respects it appears to be a fairly typical arthrobacter.

Cluster $l$ contained the oerskoviae, kurthiae and all the 'legitimate' (see Keddie, 1978) arthrobacters except $A$. globiformis NCIB 9220. Differentiation between these taxa on the basis of their fatty acid composition was not always possible, although separation of branched- $\mathrm{C}_{15}$ acids into their iso and anteiso components (see above) would have clearly distinguished the kurthiae from the arthrobacters. The ratio of the two components to each other was vastly different between these groups, even though the total amounts of branched- $\mathrm{C}_{15}$ acids were similar in each. In the kurthiae the amount of iso-15:0>anteiso-15:0, whereas in the arthrobacters the amount of anteiso-15:0 》 iso-15:0. In fact when the proportions of isoand anteiso-15:0 acids were recorded separately, cluster analysis placed the kurthiae outside Group 2.

Most of the arthrobacters were separated from the oerskoviae, but A. globiformis NCIB 8717 and 9458 clustered closely with the latter group. There is no evidence to suggest that these two strains are similar to the oerskoviae in other respects, but Collins \& Jones (1981) consider NCIB 9458 not to be a true arthrobacter either. 'Brevibacterium sulfureum' NCIB 10535, Corynebacterium liquefaciens NCIB 9545 (see also below), Flavobacterium marinotypicum NCMB 559 and 1050 and 'Brevibacterium erythrogenes' NCMB 5 clustered with most of the arthrobacters. Nocardia cellulans NCIB 8868, 'Corynebacterium manihot' NCIB 9097 and Brevibacterium fermentans NCIB 9943 clustered with the oerskoviae. These findings support previous evidence and suggestions that these eight strains are misclassified and that the first five belong to the genus Arthrobacter and the last three to the genus Oerskovia (Goodfellow, 1971; Bousfield, 1972; Yamada \& Komagata, 1972; Schleifer \& Kändler, 1972; Jones, 1975; Keddie \& Cure, 1977, 1978; Minnikin et al., 1978, 1979; Bousfield, 1978; Collins et al., 1979). However, the menaquinone composition of ' $B$. sulfureum' differs from that of most other arthrobacters (Collins et al., 1979; Collins \& Jones, 1981). The clustering of Cellulomonas cartae NCIB 11440 with the oerskoviae is supported by the presence of lysine in its cell wall (Stackebrandt \& Kändler, 1979; the present work) and by the occurrence of an extensive, fragmenting, substrate mycelium, both of which are characteristics of the genus Oerskovia.

The remaining strain in cluster $l$, 'Curt. psychrophilum' NCMB 2068 fell into cluster $l$, rather than into cluster $k$ (which contained all the other curtobacteria examined) largely because of its relatively low proportions of branched $\mathrm{C}_{17}$ acids. The other properties of 'Curt. psychrophilum' resemble those of the curtobacteria of cluster $k$ (Inoue \& Komagata, 1976), although we have found DAB in its cell wall, not ornithine as reported by Inoue \& Komagata (1976). The necessarily low incubation temperature $\left(15^{\circ} \mathrm{C}\right)$ used here for 'Curt. psychrophilum' may have influenced its fatty acid composition and, although we have included the results for this strain, we are not certain of the validity of their comparison with those of the other organisms examined. 
Brevibacterium acetylicum NCIB 9889 was an outlying strain in subgroup D, unusual in having $17 \%$ of branched $\mathrm{C}_{13}$ acids and $16 \%$ of an unidentified acid absent from all other strains studied. This strain does not have coryneform morphology and to some extent it resembles the kurthiae in that it has lysine as the cell wall diamino acid (Schleifer \& Kändler, 1972; Keddie \& Cure, 1977) and menaquinones with predominantly seven isoprene units (MK-7) (Collins, 1978; Collins et al., 1979); indeed Collins \& Jones (1981) suggested that it should be compared further with these organisms. However, its fatty acid composition is clearly different from that of the kurthiae and its DNA base composition $(51.5 \mathrm{~mol} \% \mathrm{G}+\mathrm{C})$ is not in the range $(38-40 \%)$ associated with the kurthiae. On the other hand, the DNA base composition of B. acetylicum is not far removed (about $5 \%$ ) from those of the alkalophilic organisms described by Souza \& Deal (1977) and Gee et al. (1980). Although we have not examined cultures of these organisms, from their published descriptions there do seem to be other similarities between them and $B$. acetylicum which might be worth investigating further.

Where direct comparisons are possible, our results for the strains in Group 2 compare favourably with those of other workers in that we have found the same acids to predominate (Bowie et al., 1972; Minnikin et al., 1979; Collins, 1978; Collins et al., 1980a, b; Collins \& Jones, 1980; Goodfellow et al., 1980), but in some cases there is considerable disagreement over the relative amounts and proportions of these acids. Thus our findings concur broadly with those of Bowie et al. (1972) and Collins (1978) in that the major acids in brevibacteria, curtobacteria, kurthiae and the DAB-containing coryneforms were iso- and anteiso- $\mathrm{C}_{15}$ and $\mathrm{C}_{17}$ acids, with the former usually predominating (often substantially). However, Goodfellow et al. (1980) and Collins et al. (1980b), found, and Collins et al. (1980a) and Collins \& Jones (1980) sometimes found, much lower amounts of $\mathrm{C}_{15}$ acids than we did (particularly in the kurthiae and brevibacteria) and larger, often predominant, amounts of $\mathrm{C}_{17}$ acids. These discrepancies probably reflect differences in experimental conditions used by various workers and therefore need not be a cause for concern. They do, however, illustrate the need for caution when comparing the results of quantitative fatty acid analyses obtained in different laboratories.

Our findings with Cor. liquefaciens NCIB 9545 are completely at variance with those of Lanéelle et al. (1980), who reported that a culture of this strain obtained from the ATCC (ATCC 14929) had mycolic acids and the fatty acid and cell wall composition of a typical corynebacterium. Cultures of NCIB 9545 have the cell wall and fatty acid composition and phenotypic properties of a typical arthrobacter (Bousfield, 1972; Keddie \& Cure, 1977; the present work). Schleifer \& Kändler (1972) also reported a lysine-containing peptidoglycan in their culture of ATCC 14929. We obtained recently (1981) a culture of ATCC 14929 from the ATCC and found it to have lysine in the cell wall and a fatty acid composition identical with that of NCIB 9545. Thus it appears that the culture examined by Lanéelle et al. (1980) was not authentic and that Cor. liquefaciens NCIB 9545 (ATCC 14929) is in fact an arthrobacter.

\section{Identification of coryneform bacteria by fatty acid fingerprinting}

The results of the present study confirm and extend the findings of previous workers that the detailed fatty acid composition of coryneform bacteria is of value in their classification (see Introduction for references). Of course, like any other taxonomic criterion, it must be used in conjunction with other features to arrive at sound classifications of the organisms being studied. In this respect, it is interesting that where the taxonomic position of an organism is equivocal when based on other criteria, the placement according to fatty acid composition may be similarly ambiguous (e.g. the caseobacters); also unusual organisms appear to have unusual fatty acid compositions (e.g. the LL-DAP-containing coryneforms). However, fatty acid composition differs from most taxonomic criteria in that it comprises a set of variable 'subfeatures' which are amenable to objective analysis by numerical taxonomic methods. It is this property which makes fatty acid fingerprinting, like pyrolysis GLC (see e.g. Gutteridge \& Norris, 1979) potentially valuable as an identification method. The present work did not in itself involve identification, but using the data and the similarity measure introduced here, an unknown organism could be assigned to the groups or strains to which it was a nearest neighbour. In fact this approach is now used routinely in the NCIB identification service. 
A major aim of the present work was to determine to what extent fatty acid composition with the aid of numerical analysis might be used as a principal criterion for the identification, at least to generic level, of coryneform bacteria; in particular to what extent it might obviate the need for cell wall or other chemotaxonomic analyses. The results show that not all generic groupings can be distinguished unequivocally by fatty acid composition (Figs 2 and 3) and that therefore identification solely on this basis may not be feasible. Nevertheless, our experience in the routine identification of isolates submitted to the NCIB suggests that once an organism has been placed in the appropriate subgroup or cluster (Figs 2 and 3) according to its fatty acid profile, if its identity is not then immediately apparent, a morphological examination (which must be done anyway to ascertain that the organism is a coryneform) is often the only other test needed to reach a presumptive generic (or equivalent) identification, without resort to other chemotaxonomic analyses. Thus although arthrobacters and oerskoviae (which also both have lysine as the cell wall diamino acid) are not completely separated by their fatty acid profiles, they are readily distinguished from each other morphologically. Cellulomonads can generally be recognized by their fatty acid profile alone, but in doubtful cases morphology again distinguishes them from arthrobacters and oerskoviae. Brevibacteria and curtobacteria have similar fatty acid compositions but they too can usually be distinguished morphologically, but the differences are not always pronounced and cell wall analysis may sometimes be needed in doubtful cases. On the other hand, the morphologically similar arthrobacters, brevibacteria and saprophytic corynebacteria are clearly separated from each other by their fatty acid composition, and in general corynebacteria can be distinguished from rhodococci (which have the same cell wall composition). As has been mentioned by Minnikin et al. (1978), the presence or absence of significant amounts of 10-Me18 acids can be a useful indicator here, although Lechevalier $e t$ al. (1977) have reported the occurrence of these acids in Corynebacterium bovis. Similarly, 10-Me18 acids are helpful in the distinction between caseobacters and corynebacteria and in the recognition of the $A$. simplex/tumescens group. However, fatty acid analyses do not fully separate rhodocoddi, mycobacteria, nocardiae and the ' $G$. aurantiaca' taxon and in many cases morphology is of little help either. Similarly the curtobacteria, $M$. lacticum and the DABcontaining coryneforms cannot be readily distinguished from each other. Nevertheless, despite these drawbacks we believe that detailed fatty acid analysis may be one of the most useful and widely applicable tools presently available for the routine presumptive identification of coryneform bacteria at the generic level.

It should be noted that certain of the extracts analysed in the present study will also contain mycolic acid methyl esters, which on gas chromatography may pyrolyse to give fatty acid methyl esters and long-chain aldehydes (Collins et al., 1982). It has been shown by Guerrant et al. (1981) that, for mycobacteria, the contribution of mycolic ester pyrolysis products to the overall profile depends on the injection temperature of the gas chromatograph. The present conditions approximate to those which do not promote efficient mycolate pyrolysis but, in order to reproduce the profiles obtained in these studies, similar gas chromatographic conditions should be employed.

The authors thank Dr R. Hardy for advice on the extraction and analysis of fatty acids, Drs M. Goodfellow, M. D. Collins and D. E. Minnikin for preprints of papers in press, and Dr A. McGill for the mass spectrometry analysis.

\section{REFERENCES}

Abe, S., Takayama, K. \& Kinoshita, S. (1967). Taxonomical studies on glutamic acid-producing bacteria. Journal of General and Applied Microbiology 13, 279-301.

Alshamaony, L., Goodfellow, M., Minnikin, D. E., BowDEN, G. H. \& HaRdie, J. M. (1977). Fatty acid and mycolic acid composition of Bacterionema matruchotii and related organisms. Journal of General Microbiology 98, 205-213.
Barksdale, L., Lanéelle, M. A., Pollice, M. C., Asselineau, J., Welby, M. \& Norgard, M. V. (1979). Biological and chemical basis for the reclassification of Microbacterium flavum Orla-Jensen as Corynebacterium flavescens nom. nov. International Journal of Systematic Bacteriology 29, 222233.

Baumgarten, J., ReH, M. \& Schlegel, H-G. (1974). Taxonomic studies on some Gram-positive coryne- 
form hydrogen bacteria. Archives of Microbiology 100, 207-217.

Block, R. J., Durrum, G. \& Zweig, G. (1955). A Manual of Paper Chromatography and Paper Electrophoresis. New York: Academic Press.

BøE, B. \& GJERDE, J. (1980). Fatty acid patterns in the classification of some representatives of the families Enterobacteriaceae and Vibrionaceae. Journal of General Microbiology 116, 41-49.

Boone, C. J. \& Pine, L. (1968). Rapid method for characterisation of actinomycetes by cell wall composition. Applied Microbiology 16, 279-284.

BORDET, C. \& MiChel, G. (1963). Étude des acides gras isolées de plusieurs espèces de Nocardia. Biochimica et biophysica acta 70, 613-626.

Bouisset, L., Breuillard, J. \& Michel, G. (1963). Etude de l'ADN chez les Actinomycetales. Annales de l'Institut Pasteur 104, 756-770.

BousfiELD, I. J. (1972). A taxonomic study of some coryneform bacteria. Journal of General Microbiology 71, 441-455.

BouSFIELD, I. J. (1978). The taxonomy of coryneform bacteria from the marine environment. In Coryneform Bacteria, pp. 217-233. Edited by I. J. Bousfield \& A. G. Callely. London: Academic Press.

Bousfield, I. J. \& Goodfellow, M. (1976). The "rhodochrous" complex and its relationships with allied taxa. In The Biology of the Nocardiae, pp. 3965. Edited by M. Goodfellow, G. H. Brownell \& J. A. Serrano. London: Academic Press.

Bowie, I. S., Grigor, M. R., Dunckley, D. G., Loutit, M. W. \& Loutit, J. S. (1972). The DNA base composition and fatty acid constitution of some Gram-positive pleomorphic soil bacteria. Soil Biology and Biochemistry 4, 397-412.

BURTON, M. O. \& LOCHHEAD, A. G. (1953). Nutritional requirements of Arthrobacter terregens. Canadian Journal of Botany 31, 145-151.

Collins, M. D. (1978). Lipids in coryneform taxonomy. $\mathrm{Ph} . \mathrm{D}$. thesis, University of Newcastle-upon-Tyne, U.K.

Collins, M. D. \& Jones, D. (1980). Lipids in the classification and identification of coryneform bacteria containing peptidoglycans based on 2,4diaminobutyric acid. Journal of Applied Bacteriology 48, 459-470.

Collins, M. D. \& Jones, D. (1981). Distribution of isoprenoid quinone structural types in bacteria and their taxonomic implications. Microbiological Reviews 45, 316-354.

Collins, M. D., Goodfellow, M. \& Minnikin, D. E. (1979). Isoprenoid quinones in the classification of coryneform and related bacteria. Journal of General Microbiology 110, 127-136.

Collins, M. D., Goodfellow, M. \& Minnikin, D. E. $(1980 a)$. Fatty acid, isoprenoid quinone and polar lipid composition in the classification of Curtobacterium and related taxa. Journal of General Microbiology 118, 29-37.

Collins, M. D., Jones, D., Keddie, R. M. \& SNeath, P. H. A. $(1980 b)$. Reclassification of Chromobacterium iodinum (Davis) in a redefined genus Brevibacterium (Breed) as Brevibacterium iodinum nom. rev.; comb. nov. Journal of General Microbiology 120, $1-10$

Collins, M. D., Jones, D. \& Kroppenstedt, R. M.
(1981). Reclassification of Corynebacterium ilicis (Mandel, Guba \& Litsky) in the genus Arthrobacter, as Arthrobacter ilicis comb. nov. Zentralblatt für Bakteriologie, Mikrobiologie und Hygiene (I. Abteilung, Originale C) 2, 318-323.

Collins, M. D., Goodfellow, M. \& Minnikin, D. E. (1982). A survey of the structures of mycolic acids in Corynebacterium and related taxa. Journal of General Microbiology 128, 129-149.

Свомвасн, W. Н. J. (1978). Caseobacter polymorphus gen. nov., sp. nov., a coryneform bacterium from cheese. International Journal of Systematic Bacteriology 28, 354-366.

Cure, G. L. \& KedDie, R. M. (1973). Methods for the morphological examination of aerobic coryneform bacteria. In Sampling - Microbiological Monitoring of Environments, pp. 123-135. Edited by R. G. Board \& D. W. Lovelock. New York \& London: Academic Press.

DE LEY, J. (1970). Re-examination of the association between melting point, buoyant density and chemical base composition of deoxyribonucleic acid. Journal of Bacteriology 101, 738-754.

DRUCKER, D. B. (1974). Chemotaxonomic fatty acid fingerprints of some streptococci with subsequent statistical analysis. Canadian Journal of Microbiology 20, 1723-1728.

DRUCKER, D. B. (1981). Microbiological Applications of Gas Chromatography. Cambridge: Cambridge University Press.

Drucker, D. B., Griffith, C. J. \& Melville, T. H. (1976). Fatty acid fingerprints of some chemostatgrown streptococci with computerized data analysis. Microbios Letters 1, 31-34.

Federov, M. V. \& KalininsKaya, T. A. (1961). The relation of the nitrogen-fixing mycobacterium (Mycobacterium sp. 301) to various carbon sources and to additional growth factors. Mikrobiologiya 30 , 833-840.

Fulco, A. J., Levy, R. \& Bloch, K. (1964). The biosynthesis of $\Delta^{9}$ - and $\Delta^{5}$-monosaturated (sic) fatty acids by bacteria. Journal of Biological Chemistry 239, 998-1003.

Gee, J. M., Lund, B. M., Metcalf, G. \& Peel, J. L. (1980). Properties of a new group of alkalophilic bacteria. Journal of General Microbiology 117, 9-17.

Gibson, D. M. \& OGDEN, I. D. (1979). A rapid method for purifying bacterial deoxyribonucleic acid. Journal of Applied Bacteriology 46, 421-423.

GoodfEllow, M. (1971). Numerical taxonomy of some nocardioform bacteria. Journal of General Microbiology 69, 33-80.

Goodfellow, M. \& Alderson, G. (1977). The actinomycete-genus Rhodococcus: a home for the "rhodochrous" complex. Journal of General Microbiology 100, 99-122.

Goodfellow, M., Orlean, P. A. B., Collins, M. D., Alshamaony, L. \& Minnikin, D. E. (1978). Chemical and numerical taxonomy of strains received as Gordona aurantiaca. Journal of General Microbiology 109, 57-68.

Goodfellow, M., Collins, M. D. \& Minnikin, D. E. (1980). Fatty acid and polar lipid composition in the classification of Kurthia. Journal of Applied Bacteriology 48, 269-276.

Goodfellow, M., Minnikin, D. E., TodD, C., 
Alderson, G., Minnikin, S. M. \& Collins, M. D. (1982). Numerical and chemical classification of Nocardia amarae. Journal of General Microbiology 128, 1283-1297.

Guerrant, G. O., Lambert, M. A. \& Moss, C. W. (1981). Chromatographic analysis of mycolic acid cleavage products in mycobacteria. Journal of Clinical Microbiology 13, 899-907.

Gutteridge, C. S. \& NorRIS, J. R. (1979). The application of pyrolysis techniques to the identification of micro-organisms. Journal of Applied Bacteriology 47, 5-44.

HOARE, D. S. \& WORK, E. (1955). The stereoisomers of $\alpha, \varepsilon$-diaminopimelic acid : their distribution in nature and behaviour towards certain enzyme preparations. Biochemical Journal 61, 562-568.

Ikemoto, S., Kuraishi, H., Komagata, K., Azuma, R., Suto, T. \& Murooka, H. (1978). Cellular fatty acid composition in Pseudomonas species. Journal of General and Applied Microbiology 24, 199-213.

Inoue, K. \& Komagata, K. (1976). Taxonomic study on obligately psychrophilic bacteria isolated from Antarctica. Journal of General and Applied Microbiology 22, 165-176.

Jantzen, E., Bergan, T. \& Bøvre, K. (1974a). Gas chromatography of bacterial whole cell methanolysates. VI. Fatty acid composition of strains within Micrococcaceae. Acta pathologica et microbiologica scandinavica, Section B 82, 785-798.

JANTZEN, E., BRYN, K., Bergan, T. \& BøVRe, K. $(1974 b)$. Gas chromatography of bacterial whole cell methanolysates. $\boldsymbol{V}$. Fatty acid composition of Neisseriae and Moraxellae. Acta pathologica et microbiologica scandinavica, Section B 82, 769-779.

JANTZEN, E., BRYN, K., Bergan, T. \& BøVRe, K. (1975). Gas chromatography of bacterial whole cell methanolysates. VII. Fatty acid composition of Acinetobacter in relation to the taxonomy of Neisseriaceae. Acta pathologica et microbiologica scandinavica, Section B 83, 569-580.

JONES, D. (1975). A numerical taxonomic study of coryneform and related bacteria. Journal of General Microbiology 87, 52-96.

Jones, L. A. \& Bradley, S. G. (1964). Phenetic classification of actinomycetes. Developments in Industrial Microbiology 5, 267-272.

KeDdie, R. M. (1978). What do we mean by coryneform bacteria? In Coryneform Bacteria, pp. 112. Edited by I. J. Bousfield \& A. G. Callely. London: Academic Press.

KedDIE, R. M. \& Bousfield, I. J. (1980). Cell wall composition in the classification and identification of coryneform bacteria. In Microbiological Classification and Identification, pp. 167-187. Edited by $\mathrm{M}$. Goodfellow \& R. G. Board. London: Academic Press.

Keddie, R. M. \& Cure, G. L. (1977). The cell wall composition and distribution of free mycolic acids in named strains of coryneform bacteria and in isolates from various natural sources. Journal of Applied Bacteriology 42, 229-252.

Keddie, R. M. \& Cure, G. L. (1978). Cell wall composition of coryneform bacteria. In Coryneform Bacteria, pp. 47-83. Edited by I. J. Bousfield \& A. G. Callely. London: Academic Press.

KropPenstedT, R. M. \& KuTZNER, H. J. (1978). Bio- chemical taxonomy of some problem actinomycetes. Zentrablatt für Bakteriologie, Parasitenkunde, Infektionskrankheiten und Hygiene (I. Abteilung) Suppl. 6, 125-133.

Lanéelle, M-A., Asselineau, J., Welby, M., NorGard, M. V., Imaeda, T., Pollice, M. C. \& BARKSDALE, L. (1980). Biological and chemical bases for the reclassification of Brevibacterium vitarumen (Bechdel et al.) Breed (Approved Lists 1980) as Corynebacterium vitarumen (Bechdel et al.) comb. nov. and Brevibacterium liquefaciens Okabayashi \& Masuo (Approved Lists 1980) as Corynebacterium liquefaciens (Okabayashi \& Masuo) comb. nov. International Journal of Systematic Bacteriology 30, 539546.

Lechevalier, M. P. (1977). Lipids in bacterial taxonomy - a taxonomist's view. CRC Critical Reviews in Microbiology 5, 109-210.

Lechevalier, M. P., De Bièvre, C. \& Lechevalier, H. A. (1977). Chemotaxonomy of aerobic actinomycetes: phospholipid composition. Biochemical Systematics and Ecology 5, 249-260.

MALIK, K. A. \& ClaUS, D. (1979). Xanthobacter flavus, a new species of nitrogen-fixing hydrogen bacteria. International Journal of Systematic Bacteriology 29, 283-287.

MARMUR, J. \& Doty, P. (1962). Determination of the base composition of deoxyribonucleic acid from its thermal denaturation temperature. Journal of Molecular Biology 5, 109-118.

Metcalfe, L. D. \& Schmitz, A. A. (1961). The rapid preparation of fatty acid esters for gas chromatographic analysis. Analytical Chemistry 33, 363-364.

MinNikin, D. E. \& Goodfellow, M. (1976). Lipid composition in the classification and identification of nocardiae and related taxa. In The Biology of the Nocardiae, pp. 160-169. Edited by M. Goodfellow, M. Brownell \& J. A. Serrano. London: Academic Press.

MinNikin, D. E. \& GoOdfellow M. (1980). Lipid composition in the classification and identification of acid-fast bacteria. In Microbiological Classification and Identification, pp. 189-256. Edited by $M$. Goodfellow \& R. G. Board. London: Academic Press.

Minnikin, D. E., Goodfellow, M. \& Collins, M. D. (1978). Lipid composition in the classification and identification of coryneform bacteria and related taxa. In Coryneform Bacteria, pp. 85-160. Edited by I. J. Bousfield \& A. G. Callely. London: Academic Press.

Minnikin, D. E., Collins, M. D. \& Goodfellow, $\dot{M}$. (1979). Fatty acid and polar lipid composition in the classification of Cellulomonas, Oerskovia and related taxa. Journal of Applied Bacteriology 47, 87-95.

Nesterenko, O. A., ANDReEV, L. V., Nogina, T. M. \& ShKaruba, V. U. (1980). Fatty acid composition of some coryneform and nocardioform bacteria. Mikrobiologicheskii zhurnal 42, 288-293.

ORChaRD, V. A., Goodfellow, M. \& Williams, S. T (1977). Selective isolation and occurrence of nocardiae in soil. Soil Biology and Biochemistry 9, 233-238.

Pommier, M. T. \& Michel, G. (1973). Phospholipid and acid composition of Nocardia and nocardoid bacteria as criteria of classification. Biochemical Systematics 1, 3-12. 
RANDERATH, K. (1963). Thin Layer Chromatography (English translation). New York \& London: Academic Press.

SCHLEIFER, K-H. \& KÄNDLER, O. (1972). Peptidoglycan types of bacterial cell walls and their taxonomic implications. Bacteriological Reviews 36, 407-477.

Sharpe, M. E., Law, B. A. \& Phillips, B. A. (1976). Coryneform bacteria producing methanethiol. Journal of General Microbiology 94, 430-435.

Sharpe, M. E., Law, B. A., Phillips, B. A. \& Pitcher, D. G. (1977). Methanethiol production by coryneform bacteria: strains from dairy and human skin sources and Brevibacterium linens. Journal of General Microbiology 101, 345-349.

Skerman, V. B. D., McGowan, V. \& Sneath, P. H. A. (1980). Approved lists of bacterial names. International Journal of Systematic Bacteriology 30, 225420.

SOKAL, R. R. \& MicheneR, C. D. (1958). A statistical method for evaluating systematic relationships. University of Kansas Science Bulletin 38, 1409-1438.

SouZA, K. A. \& DEAL, P. H. (1977). Characterisation of a novel extremely alkalophilic bacterium. Journal of General Microbiology 101, 103-109.

STACKEBRANDT, E. \& KÄNDLER, O. (1979). Taxonomy of the genus Cellulomonas, based on phenotypic characters and deoxyribonucleic acid-deoxyribonucleic acid homology, and proposal of seven neotype strains. International Journal of Systematic Bacteriology 29, 273-282.

StaCkEBrandT, E., HÄringer, M. \& SchleIfER, K-H.
(1980). Molecular genetic evidence for the transfer of Oerskovia species into the genus Cellulomonas. Archives of Microbiology 127, 179-185.

Suzuki, K., Kaneko, T. \& Komagata, K. (1981). Deoxyribonucleic acid homologies among coryneform bacteria. International Journal of Systematic Bacteriology 31, 131-138.

Tsukamura, M., Mizuno, S., Tsukamura, S. \& Tsukamura, J. (1979). Comprehensive numerical classification of 369 strains of Mycobacterium, Rhodococcus and Nocardia. International Journal of Systematic Bacteriology 29, 110-129.

Weigel, J., Wilke, D., Baumgarten, J., Opitz, R. \& SCHLEGEL, H-G. (1978). Transfer of the nitrogenfixing hydrogen bacterium Corynebacterium autotrophicum Baumgarten et al. to Xanthobacter gen. nov. International Journal of Systematic Bacteriology 28, 573-581.

Yamada, K. \& Komagata, K. (1970). Taxonomic studies on coryneform bacteria III. DNA base composition of coryneform bacteria. Journal of General and Applied Microbiology 16, 215-224.

Yamada, K. \& Komagata, K. (1972). Taxonomic studies on coryneform bacteria V. Classification of coryneform bacteria. Journal of General and Applied Microbiology 18, 417-431.

Yamada, K., InouYe, G., Tahara, Y. \& Kondo, K. (1976). The menaquinone system in the classification of coryneform and nocardioform bacteria and related organisms. Journal of General and Applied Microbiology 22, 203-214. 